\title{
Analisis Partial Discharge dan Prediksi Usia Layak Isolasi Belitan Stator Generator 143,4 MVA
}

\author{
Kukuh Widodo' ${ }^{1}$ Muhamad Haddin², Gunawan ${ }^{3}$ \\ ${ }^{1,2,3}$ Teknik Elektro, Universitas Islam Sultan Agung \\ ${ }^{1}$ kukuhwi99@gmail.com \\ 2haddin@unissula.ac.id \\ ${ }^{3}$ gunawan@unissula.ac.id
}

\begin{abstract}
The arise of partial discharge in isolation of the winding stator generator is thing that general because existence ageing and excessive stress. Partial discharge in isolation of the winding stator occur in the core slot area or endwinding area. The problem that occur in isolation of the winding stator generator is the presence of corona and high partial discharge in the endwinding area caused by ineffective monitoring of partial discharge. This research discusses about that occurrence corona and partial discharge, and the effectiveness of repairing insulation of the stator winding that performed during overhaul. The analysis methods used is comparative, characteristics and trending, and linear regression to predict the age of operation worthiness in isolation of the winding stator. The results of the analysis showed that, the cause of corona and high partial discharge due to damage to the isolation surface consequence contamination from bearing seal oil which have seepage and load \& thermal cycling, with the age of operation worthiness shortest isolation of the winding stator during \pm 2 years 1 month 21 days or only increased 14 days after overhaul.
\end{abstract}

Keywords: partial discharge, corona, linear regression, age of worthiness isolation of the winding

\begin{abstract}
ABSTRAK
Timbulnya partial discharge pada isolasi belitan stator generator merupakan hal yang umum terjadi karena adanya penuaan dan tekanan yang berlebih. Partial discharge pada isolasi belitan stator terjadi di area slot inti atau area endwinding. Permasalahan yang terjadi pada isolasi belitan stator generator adalah adanya korona dan partial discharge tinggi pada area endwinding yang disebabkan karena kurang efektifnya monitoring terhadap partial discharge. Penelitian ini membahas tentang terjadinya korona dan partial discharge, serta efektifitas perbaikan isolasi belitan stator generator yang dilakukan saat overhaul. Metode analisa yang digunakan adalah komparasi, karateristik dan trending, serta regresi linear untuk memprediksi usia kelayakan operasi isolasi belitan stator. Hasil analisa menunjukkan bahwa, penyebab terjadinya korona dan partial discharge tinggi karena adanya kerusakan pada permukaan isolasi akibat kontaminasi minyak dari seal oil bearing 5 yang mengalami rembesan dan load \& thermal cycling, dengan usia kelayakan operasi tersingkat isolasi belitan stator selama \pm 2 tahun 1 bulan 21 hari atau hanya mengalami kenaikan 14 hari setelah overhaul.
\end{abstract}

Kata kunci : partial discharge, korona, regresi linear, usia layak isolasi belitan 


\section{Energi dan Kelistrikan: Jurnal Ilmiah}

Vol. 12, No. 1, Januari - Juni 2020, P-ISSN 1979-0783, E-ISSN 2655-5042

https://doi.org/10.33322/energi.v12i1.927

\section{PENDAHULUAN}

Partial discharge (PD) merupakan peluahan elektris yang terjadi pada rongga (void) yang terlokalisir, baik didalam maupun dipermukaan isolasi akibat adanya electrical stress $(3 \mathrm{kV} / \mathrm{mm})$ melebihi electrical breakdown $(300 \mathrm{kV} / \mathrm{mm})$ udara [1]. Sedangkan, korona merupakan non disruptive discharge atau disebut sebagai PD yang terjadi karena adanya ionisasi udara disekitar permukaan konduktor [2]. Timbulnya PD pada sistem isolasi disebabkan oleh penuaan (ageing) dari isolasi tersebut. PD berpotensi menyebabkan kegagalan hubung singkat (short circuit) antara fasa ke tanah (slot inti) maupun fasa ke fasa (endwinding), sehingga diperlukan adanya sistem monitoring sebagai langkah prediktif (predictive maintenance) untuk mencegah terjadinya kegagalan tersebut [3]. Sistem monitoring PD yang umum digunakan saat ini terdapat tiga jenis, namun pada generator pembangkit listrik tenaga gas (PLTG) dominan menggunakan jenis periodical online monitoring, yaitu sistem monitoring dengan satu buah alat ukur PD portabel untuk semua generator yang tersedia.

Permasalahan yang terjadi dalam penelitian ini adalah timbulnya korona dan PD yang tinggi pada isolasi belitan stator generator saat dilakukan pemeliharaan periodik overhaul. Hal ini disebabkan karena kurang efektifnya monitoring terhadap PD, dimana monitoring yang dilakukan masih sebatas pengukuran dan mencatat nilai PD yang terukur, sehingga diperlukan adanya analisa guna mengetahui penyebab terjadinya korona dan PD serta efektifitas perbaikan yang dilakukan saat overhaul.

Beberapa penelitian terdahulu tentang PD dan prediksi usia isolasi belitan stator yang telah dilakukan antara lain: pengukuran PD secara online pada generator dengan pendingin $\mathrm{H}_{2}$ yang mampu mendeteksi belitan yang longgar dan terkontaminasi bahan konduktif [4], analisa PD pada generator menggunakan metode komparasi, trending dan karateristik yang dikeluarkan oleh Iris Power Engineering. Inc. [5], dan prediksi usia efektif isolasi belitan stator menggunakan metode regresi linear [6]. Penelitian ini memfokuskan tentang analisis PD dan prediksi usia layak operasi pada isolasi belitan stator generator, dengan menggunakan metode dari Iris Power Engineering. Inc. dan regresi linear.

\section{METODE DAN PERANCANGAN PENELITIAN}

Metode komparasi merupakan metode analisa yang dilakukan dalam dua tahapan. Tahap pertama dengan membandingkan nilai PD dengan mesin yang identik (mesin dengan parameter operasi yang sama dan menggunakan instrument dan metode pengukuran PD yang sama) dan tahap kedua dengan membandingkan nilai PD dengan data relative severity [8], seperti yang ditunjukkan pada Tabel 1 .

Tabel 1. Data Relative Severity [7]

\begin{tabular}{|c|c|c|c|c|c|c|c|}
\hline \multicolumn{2}{|c|}{ PARAMETER } & \multicolumn{6}{c|}{ LEVEL } \\
\hline \multirow{2}{*}{$\begin{array}{c}\text { Teganga } \\
\text { n (kV) }\end{array}$} & \multirow{2}{*}{$\mathbf{1 3 - 1 5}$} & $\begin{array}{c}\text { Negligibl } \\
\boldsymbol{e}\end{array}$ & Low & Typical & Moderate & High & Very High \\
\cline { 3 - 8 } & & $<\mathbf{2 5 \%}$ & $\begin{array}{c}< \\
\mathbf{5 0 \%}\end{array}$ & $<\mathbf{7 5 \%}$ & $<\mathbf{9 0 \%}$ & $<\mathbf{9 5 \%}$ & $>\mathbf{9 5 \%}$ \\
\hline H2 (Psig) & $\mathbf{2 1 - 3 0}$ & $<19$ & 19 & 48 & 92 & 172 & 284 \\
\hline
\end{tabular}

Metode karateristik merupakan metode analisa yang menggunakan grafik phase resolved partial discharge (PRPD) untuk mengolah data hasil pengukuran PD. Pada grafik PRPD dapat diketahui mekanisme kegagalan dan lokasi PD yang terjadi, baik pada area slot (terjadi pada sudut 
$45^{\circ}$ dan $225^{\circ}$ ) maupun endwinding (terjadi diluar sudut $45^{\circ}$ dan $225^{\circ}$ ) belitan stator [8]. Mekanisme kegagalan area slot antara lain: partial discharge no predominance $\left(45^{\circ}\right.$ dan $\left.225^{\circ}\right)$, positive predominance $\left(225^{\circ}\right)$ dan negative predominance $\left(45^{\circ}\right)$. Sedangkan, mekanisme kegagalan area endwinding antara lain: mechanicaly dependent $\left(0^{\circ}\right.$ dan $\left.180^{\circ}\right)$, open air arc $\left(90^{\circ}\right.$ dan $\left.270^{\circ}\right)$ dan broken strands $\left(0^{\circ} / 180^{\circ}\right)$ [8]. Metode trending merupakan metode analisa yang membandingkan hasil pengukuran PD saat ini dengan hasil pengukuran PD sebelumnya. Metode ini menghasilkan grafik yang mempresentasikan proses penuaan isolasi dengan menampilkan data NQN (Normalized Quantity Number), Qm (Magnitudo), daya aktif (Watt) dan temperatur belitan $\left({ }^{0} \mathrm{C}\right.$ ) [8]. Sedangkan, regresi linear merupakan metode statistik yang menerangkan hubungan antara satu variabel bebas $\mathrm{X}$ (predictor) dengan satu variabel tak bebas $\mathrm{Y}$ (response) dan digambarkan garis lurus [9] dengan menggunakan persamaan (1):

$$
Y=a+b X
$$

dengan, $Y=$ variabel tak bebas/garis regresi, $X=$ variabel bebas, $a=$ konstanta regresi/intersep (perpotongan dengan sumbu $\mathrm{Y}$ ), dan $b=$ konstanta regresi/slope. Nilai konstanta $a$ dan $b$ dapat ditentukan dengan menggunakan persamaan (2) dan (3) :

$$
\begin{aligned}
& a=\frac{\sum x^{2} \sum y-\sum x \sum x y}{n \sum x^{2}-\left(\sum x\right)^{2}} \\
& b=\frac{n \sum x y-\sum x \sum x y}{n \sum x^{2}-\left(\sum x\right)^{2}}
\end{aligned}
$$

dengan, $n=$ jumlah data. Besarnya standard error of estimate menggunakan persamaan (4):

$$
S_{y . x}=\sqrt{\frac{\sum y^{2}-a \sum y-b \sum x y}{n}}
$$

\subsection{Model Penelitian}

Penelitian mengambil objek pada Gas Turbine Generator (GTG) 143,4 MVA Unit 1 PLTG Jawa Tengah. Penelitian dilakukan dalam tiga tahapan antara lain: tahap pertama dengan melakukan analisa dan perhitungan data pengukuran PD sebelum periode overhaul. Pada tahap ini akan terlihat nilai dan mekanisme PD yang terjadi. Tahap kedua dengan melakukan identifikasi kondisi fisik secara visual dan pengujian korona pada isolasi belitan stator saat periode overhaul. Selama periode ini, isolasi belitan dilakukan perbaikan untuk mengembalikan kondisinya. Tahap ketiga dengan melakukan analisa dan perhitungan kembali data pengukuran PD setelah periode overhaul dan akan terlihat nilai dan mekanisme PDnya. Pengukuran PD dilakukan secara online saat generator beroperasi, dengan model rangkaian pengukuran jenis double ended capacitive coupler, seperti yang ditunjukkan pada Gambar 1. 


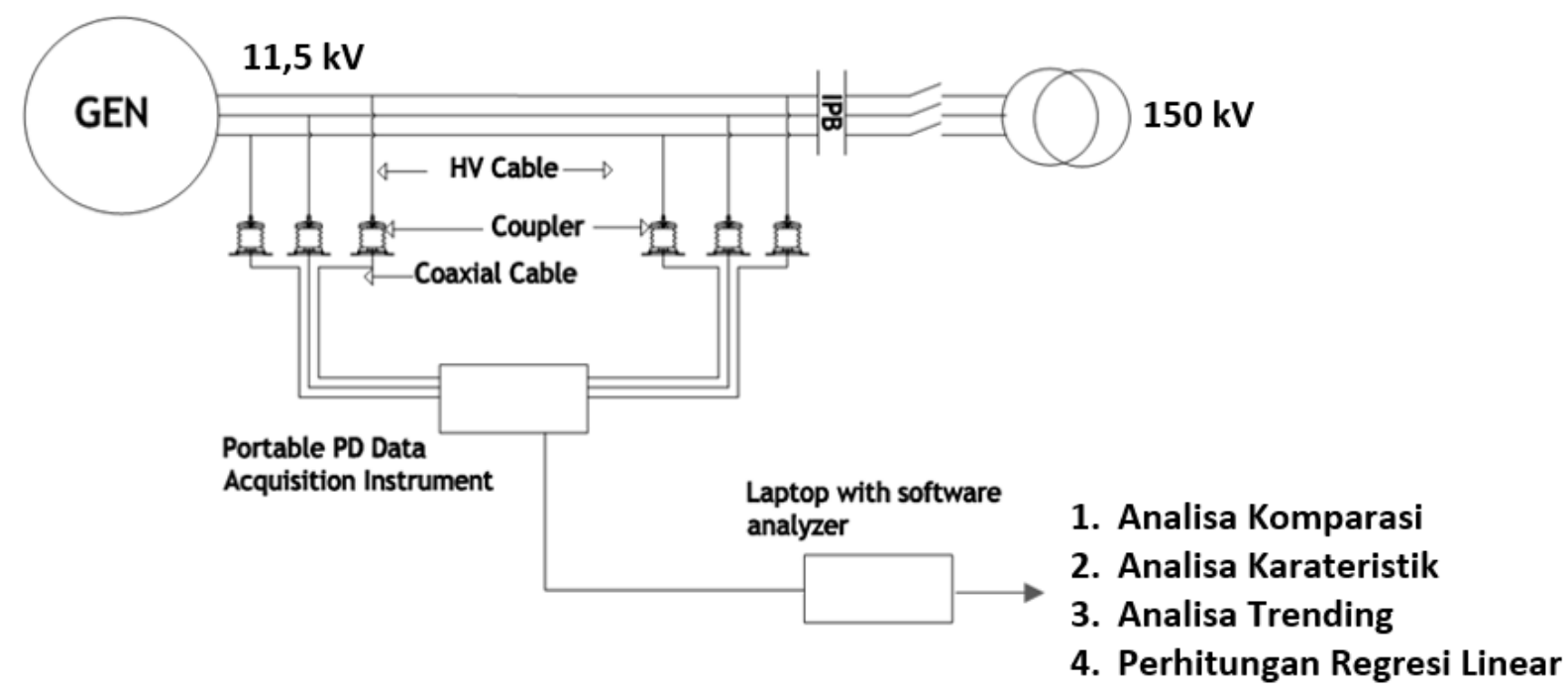

Gambar 1. Model Rangkaian Pengukuran Partial Discharge [1]

dengan data spesifikasi generator Unit 1 ditunjukkan pada Tabel 2.

Tabel 2. Spesifikasi Generator Unit 1 [10]

\begin{tabular}{|l|l|}
\hline \multicolumn{1}{|c|}{ Nama } & \multicolumn{1}{c|}{ Keterangan } \\
\hline Model & $:$ GE9001E \\
\hline Jumlah Kutub & $: 2 /$ Wye \\
\hline Kecepatan & $: 3000 \mathrm{rpm}$ \\
\hline Frekuensi & $: 50 \mathrm{~Hz}$ \\
\hline Pendingin & $:$ Hidrogen/ 30 Psig \\
\hline Daya Semu & $: 143400 \mathrm{kVA}$ \\
\hline Tegangan Stator & $: 11,5 \mathrm{kV}$ \\
\hline Arus Stator & $: 7199 \mathrm{~A}$ \\
\hline Tegangan Eksitasi & $: 500 \mathrm{~V}$ \\
\hline Arus Eksitasi & $: 1283 \mathrm{~A}$ \\
\hline Faktor Daya & $: 0,8$ \\
\hline Kelas Isolasi & $: \mathrm{F}\left(155^{0} \mathrm{C}\right) /$ Epoxy Mica \\
\hline Konfigurasi Belitan & $:$ Multi Turn Coil \\
\hline
\end{tabular}




\subsection{Tahapan Penelitian}

Tahapan penelitian pada generator Unit 1 diperlihatkan pada Gambar 2.
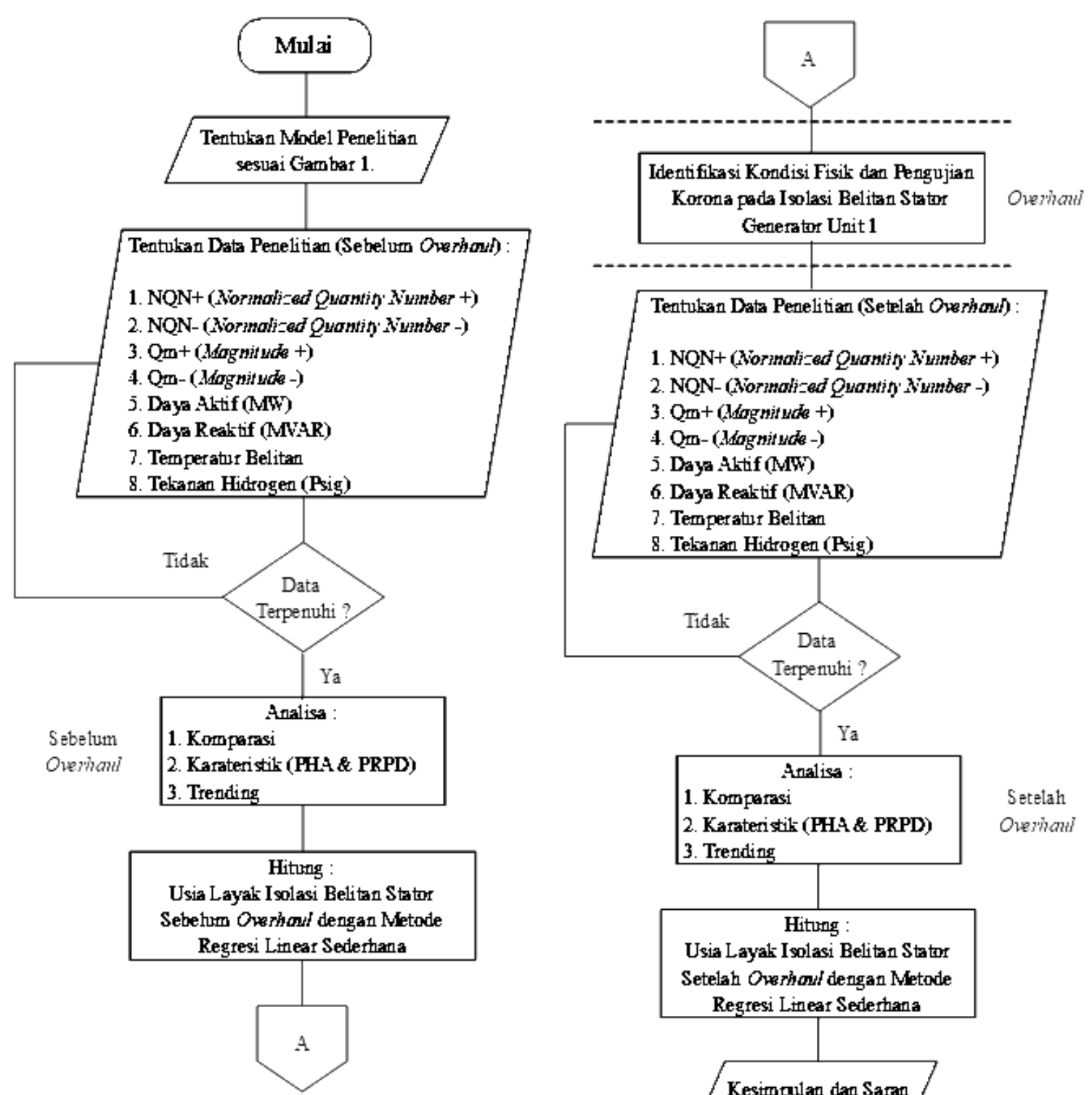

8. Telanan Hidrogen (Psig)

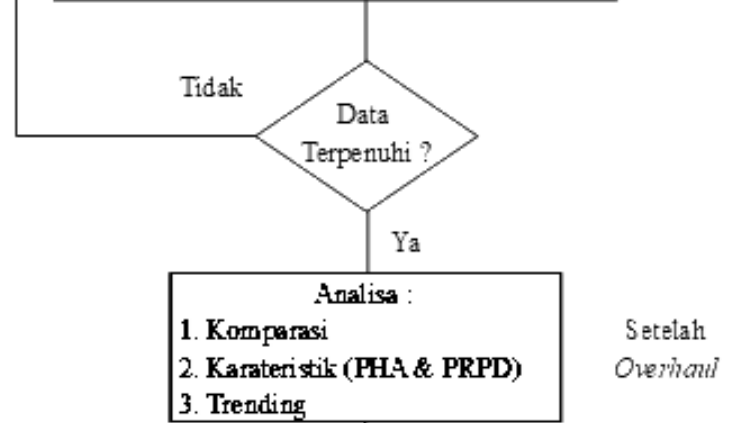

Usia Layak Isolasi Belitan Stator behm Owshouldengan Metode Si Linear Sederhana

Gambar 2. Tahapan Penelitian

Selesai

\section{HASIL DAN PEMBAHASAN}

\subsection{Analisa Partial Discharge Sebelum Overhaul}

Data pengukuran sebelum overhaul yang digunakan dalam penelitian ditunjukkan pada Tabel 3. 
Tabel 3. Data Pengukuran Partial Discharge Sebelum Overhaul

\begin{tabular}{|c|c|c|c|c|c|c|c|c|c|}
\hline \multirow[b]{2}{*}{ Fasa } & \multirow[b]{2}{*}{ Tanggal } & \multicolumn{2}{|c|}{ Daya } & \multirow{2}{*}{$\begin{array}{c}\text { Temp } \\
\text { Belitan } \\
\left({ }^{0} \mathrm{C}\right)\end{array}$} & \multirow{2}{*}{$\begin{array}{c}\mathbf{H}_{2} \\
\text { (Psig) }\end{array}$} & \multirow{2}{*}{ NQN+ } & \multirow{2}{*}{ NQN- } & \multirow[b]{2}{*}{ Qm+ } & \multirow[b]{2}{*}{ Qm- } \\
\hline & & MW & MVAR & & & & & & \\
\hline \multirow{5}{*}{$\mathbf{R}$} & $31 / 7 / 2017$ & 95.3 & 0.2 & 84 & 25 & 188 & - & 52 & 59 \\
\hline & $22 / 12 / 2017$ & 49.2 & 9.8 & 52 & 28 & 69 & 67 & 37 & 33 \\
\hline & $3 / 1 / 2018$ & 80 & 1.1 & 63 & 26.4 & - & 142 & 52 & 60 \\
\hline & $30 / 5 / 2018$ & 65.5 & 0.4 & 78 & 24.1 & 122 & 186 & 62 & 103 \\
\hline & $16 / 10 / 2018$ & 75 & 2.1 & 94 & 28 & 72 & 202 & 51 & 122 \\
\hline \multirow{5}{*}{$\mathbf{S}$} & $31 / 7 / 2017$ & 95.3 & 0.2 & 84 & 25 & 82 & 112 & 38 & 54 \\
\hline & $22 / 12 / 2017$ & 49.2 & 9.8 & 52 & 28 & 99 & 100 & 50 & 54 \\
\hline & $3 / 1 / 2018$ & 80 & 1.1 & 63 & 26.4 & 354 & 289 & 191 & 170 \\
\hline & $30 / 5 / 2018$ & 65.5 & 0.4 & 78 & 24.1 & 582 & 367 & 336 & 223 \\
\hline & $16 / 10 / 2018$ & 75 & 2.1 & 94 & 28 & 480 & 176 & 228 & 115 \\
\hline \multirow{5}{*}{$\mathbf{T}$} & $31 / 7 / 2017$ & 95.3 & 0.2 & 84 & 25 & 297 & 265 & 141 & 115 \\
\hline & $22 / 12 / 2017$ & 49.2 & 9.8 & 52 & 28 & 97 & 83 & 84 & 45 \\
\hline & $3 / 1 / 2018$ & 80 & 1.1 & 63 & 26.4 & - & 152 & 47 & 72 \\
\hline & $30 / 5 / 2018$ & 65.5 & 0.4 & 78 & 24.1 & 107 & 169 & 62 & 94 \\
\hline & $16 / 10 / 2018$ & 75 & 2.1 & 94 & 28 & 59 & 175 & 35 & 85 \\
\hline
\end{tabular}

\section{A. Komparasi}

Data pengukuran pada Tabel 3 dikomparasi dengan data generator Unit 2 dan Unit 3, dengan hasil analisa menunjukkan bahwa, generator Unit 1 memiliki PD yang lebih tinggi dibandingkan dengan generator Unit 2 dan Unit 3, karena ditemukannya PD high dengan kategori $>90 \%$ pada fasa S. Sehingga, generator Unit 1 diprioritaskan untuk dilakukan inspeksi terlebih dahulu pada isolasi belitan statornya, seperti yang ditunjukkan pada Tabel 4.

Tabel 4. Analisa Komparasi Sebelum Overhaul

\begin{tabular}{|c|c|c|c|c|c|c|}
\hline \multirow{2}{*}{ Tanggal } & \multirow{2}{*}{ Generator } & Fasa & Qm+ & Qm- & \multicolumn{2}{|c|}{$\begin{array}{c}\text { Level Partial } \\
\text { Discharge }\end{array}$} \\
\hline $\begin{array}{c}\text { 10 } \\
\text { Oktober } \\
2018\end{array}$ & \multirow{2}{*}{ Unit 1 } & $\mathrm{R}$ & 51 & 122 & $<90 \%$ & Moderate \\
\cline { 3 - 7 } & & $\mathrm{S}$ & 228 & 115 & $>90 \%$ & High \\
\cline { 3 - 7 } & $\mathrm{T}$ & 35 & 85 & $<75 \%$ & Typical \\
\hline \multirow{2}{*}{2018} & \multirow{3}{*}{ Juni 2} & $\mathrm{R}$ & 14 & 14 & $<25 \%$ & Negligible \\
\cline { 3 - 7 } & & $\mathrm{S}$ & 19 & 12 & $<50 \%$ & Low \\
\cline { 3 - 7 } & $\mathrm{T}$ & 26 & 8 & $<50 \%$ & Low \\
\hline \multirow{2}{*}{$\begin{array}{c}31 \mathrm{Mei} \\
2018\end{array}$} & \multirow{2}{*}{ Unit 3 } & $\mathrm{R}$ & 9 & 13 & $<25 \%$ & Negligible \\
\cline { 3 - 7 } & & $\mathrm{S}$ & 63 & 27 & $<75 \%$ & Typical \\
\cline { 3 - 7 } & $\mathrm{T}$ & 35 & 35 & $<50 \%$ & Low \\
\hline
\end{tabular}

\section{B. Karateristik}

Hasil analisa data pengukuran dengan grafik PRPD pada Tabel 5 menunjukkan bahwa, fasa $\mathrm{R}$ mengalami mechanical dependent $\left(180^{\circ}\right)$ artinya terjadi kelonggaran pada koneksi terminal generator atau pada belitan slot stator (loose winding) akibat vibrasi, fasa $\mathrm{S}$ mengalami partial discharge classic negative predominance $\left(45^{\circ}\right.$ dan $\left.225^{\circ}\right)$ artinya terdapat rongga (void) didalam isolasi yang berada dekat dengan konduktor belitan (delaminasi) akibat pola 
operasi generator yang cepat berubah (load and thermal cycling) dan fasa T mengalami open air arc/korona $\left(90^{\circ}\right.$ dan $\left.270^{\circ}\right)$ artinya terdapat deteriorasi pada permukaan isolasi area endwinding akibat kontaminasi atau kotoran lain yang menempel isolasi.

Tabel 5. Analisa Karateristik Sebelum Overhaul

\begin{tabular}{|c|c|c|}
\hline \multicolumn{3}{|c|}{ Pola Sinyal Partial Discharge } \\
\hline Fasa $\mathbf{R}$ & Fasa $\mathrm{S}$ & Fasa T \\
\hline 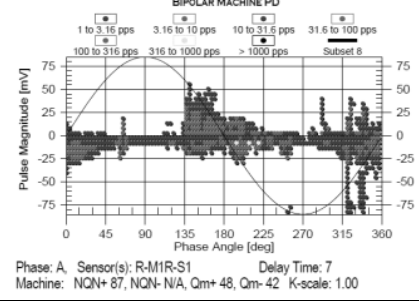 & 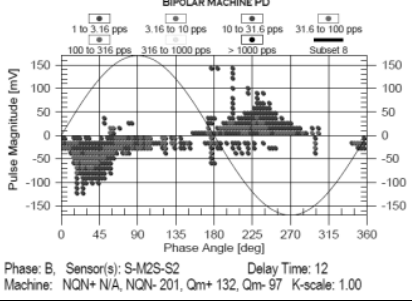 & 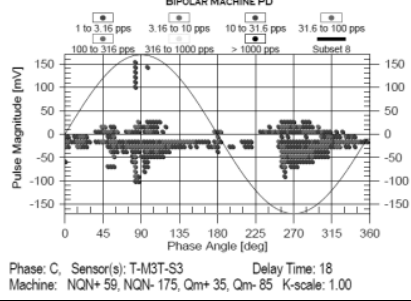 \\
\hline
\end{tabular}

\section{Trending}

Berdasarkan analisa trending data pengukuran pada Tabel 6 menunjukkan bahwa, magnitudo PD mengalami fluktuasi (fluctuation). Pada fasa R PD dipengaruhi oleh temperatur belitan $\left({ }^{0} \mathrm{C}\right)$, sedangkan fasa $\mathrm{S}$ dan fasa T PD dipengaruhi oleh daya aktif generator (MW). Sehingga, untuk menurunkan PD perlu menjaga kestabilan beban dari generator dan menjaga tekanan gas hidrogen sebagai pendingin belitan sebesar 30 psig sesuai dengan nameplate.

Tabel 6. Analisa Trending Sebelum Overhaul

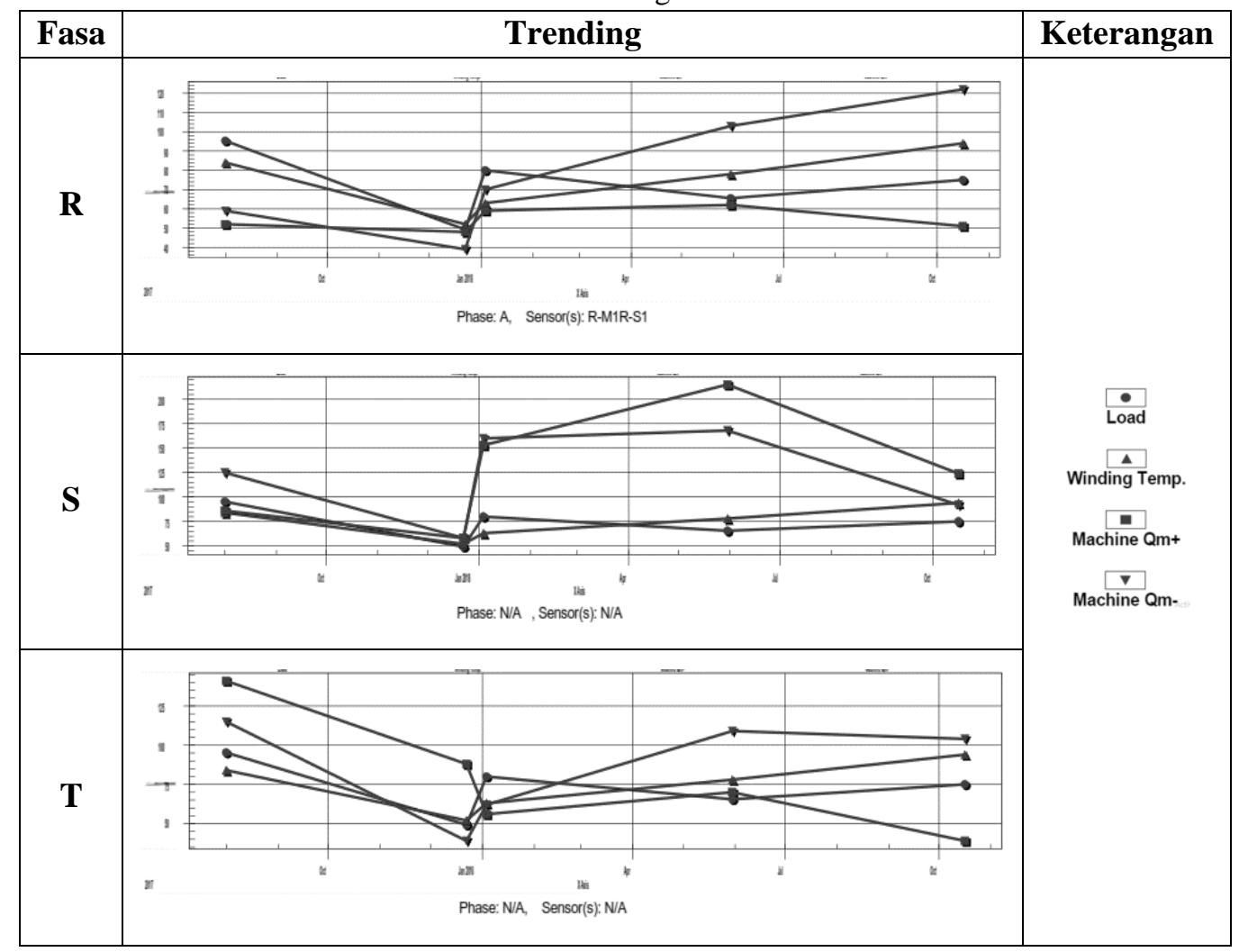




\section{Regresi Linear}

Nilai acuan yang digunakan adalah data pengukuran PD generator Unit 6 dengan nilai sebesar $439 \mathrm{mV}$ [12]. Hasil perhitungan usia layak isolasi pada Tabel 7 menunjukkan bahwa, fasa R diprediksi selama 6 tahun 5 bulan 22 hari (6,476 tahun) atau sampai dengan \pm 8 April 2024, fasa S diprediksi selama 2 tahun 1 bulan 7 hari (2,103 tahun) atau sampai dengan \pm 23 November 2020, dan fasa T diprediksi selama 6 tahun 8 bulan 7 hari (6,685 tahun) atau sampai dengan \pm 23 Juni 2024 .

Tabel 7. Perhitungan Usia Isolasi Fasa R Sebelum Overhaul

\begin{tabular}{|c|c|c|c|c|c|c|c|c|}
\hline Fasa & Tanggal & Sensitivitas & $\mathrm{X}$ & $\mathrm{Y}$ & $X^{2}$ & $\mathrm{Y}^{2}$ & XY & Fungsi $Y$ \\
\hline \multirow{6}{*}{$\mathrm{R}$} & $31 / 7 / 2017$ & \multirow{5}{*}{$20-340$} & 1 & 59 & 1 & 3481 & 59 & \multirow{6}{*}{$\begin{array}{l}\text { Fungsi } a: 33,402 \\
\text { Fungsi } b: 5,219 \\
\text { Usia }: 77,712 \text { bulan } \\
\text { (6,476 tahun) }\end{array}$} \\
\hline & $\begin{array}{c}22 / 12 / 201 \\
7\end{array}$ & & 6 & 37 & 36 & 1369 & 222 & \\
\hline & $3 / 1 / 2018$ & & 7 & 60 & 49 & 3600 & 420 & \\
\hline & $30 / 5 / 2018$ & & 11 & 103 & 121 & 10609 & 1133 & \\
\hline & $\begin{array}{c}16 / 10 / 201 \\
8\end{array}$ & & 16 & 122 & 256 & 14884 & 1952 & \\
\hline & \multicolumn{2}{|c|}{ Total $\left(\sum\right)$} & 41 & 381 & 463 & 33943 & 3786 & \\
\hline \multirow{6}{*}{ S } & $31 / 7 / 2017$ & \multirow{5}{*}{$10-170$} & 1 & 54 & 1 & 2916 & 54 & \multirow{6}{*}{$\begin{array}{l}\text { Fungsi } a: 33,402 \\
\text { Fungsi } b: 5,219 \\
\text { Usia }: 25,24 \text { bulan } \\
(2,103 \text { tahun })\end{array}$} \\
\hline & $\begin{array}{c}22 / 12 / 201 \\
7\end{array}$ & & 6 & 54 & 36 & 2916 & 324 & \\
\hline & $3 / 1 / 2018$ & & 7 & 191 & 49 & 36481 & 1337 & \\
\hline & $30 / 5 / 2018$ & & 11 & 336 & 121 & $\begin{array}{c}11289 \\
6\end{array}$ & 3696 & \\
\hline & $\begin{array}{c}16 / 10 / 201 \\
8\end{array}$ & & 16 & 228 & 256 & 51984 & 3648 & \\
\hline & \multicolumn{2}{|c|}{ Total $\left(\sum\right)$} & 41 & 863 & 463 & $\begin{array}{c}20719 \\
3\end{array}$ & 9059 & \\
\hline \multirow{6}{*}{$\mathrm{T}$} & $31 / 7 / 2017$ & & 1 & 0 & 1 & 0 & 0 & \multirow{6}{*}{$\begin{array}{l}\text { Fungsi } a: 33,402 \\
\text { Fungsi } b: 5,219 \\
\text { Usia }: 80,215 \text { bulan } \\
(6,685 \text { tahun })\end{array}$} \\
\hline & $\begin{array}{c}22 / 12 / 201 \\
7\end{array}$ & & 6 & 84 & 36 & 7056 & 504 & \\
\hline & $3 / 1 / 2018$ & $100-1700$ & 7 & 72 & 49 & 5184 & 504 & \\
\hline & $30 / 5 / 2018$ & & 11 & 94 & 121 & 8836 & 1034 & \\
\hline & $\begin{array}{c}16 / 10 / 201 \\
8\end{array}$ & & 16 & 85 & 256 & 7225 & 1360 & \\
\hline & \multicolumn{2}{|c|}{ Total $\left(\sum\right)$} & 41 & 335 & 463 & 28301 & 3402 & \\
\hline
\end{tabular}

\subsection{Identifikasi Kondisi Fisik dan Pengujian Korona}

Terdapat korona yang ditandai kotak berwarna hitam, seperti yang ditunjukkan pada Gambar 3 dan Gambar 4. Hal ini disebabkan adanya kontaminasi minyak pada tying (pemisah) belitan fasa $\mathrm{S}$ dan fasa $\mathrm{T}$ nomor 32 dan 33 area endwinding yang diprediksi berasal dari seal oil bearing karena vibrasi tinggi sebesar 13,002 mm/s (normal $<12 \mathrm{~mm} / \mathrm{s}$ ). Kontaminasi ini mengakibatkan permukaan isolasi fasa $\mathrm{S}$ dan fasa $\mathrm{T}$ yang menempel dengan tying mengalami kerusakan dan menimbulkan korona. Perbaikan yang dilakukan untuk meminimalisir korona tersebut adalah dengan cara melakukan pembersihan isolasi dari minyak dan melakukan re-varnish pada belitan area slot stator 
dan endwinding. Hal tersebut menunjukkan bahwa, terdapat kesesuaian antara analisa sebelum overhaul dengan temuan korona pada isolasi.

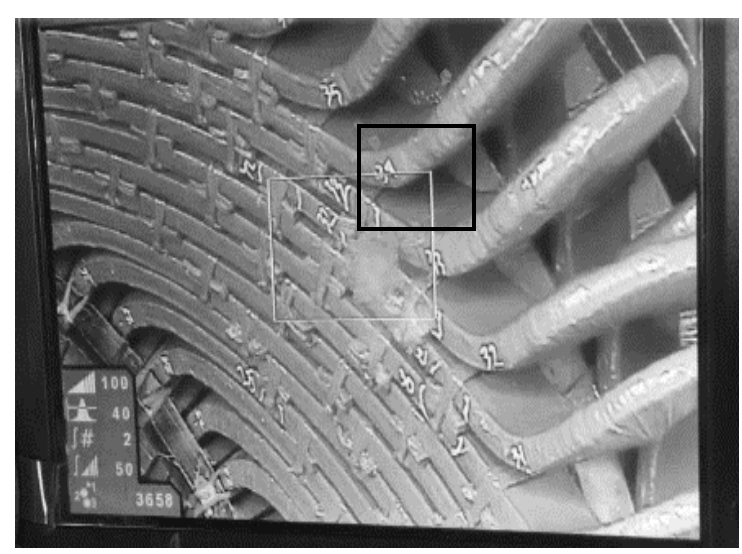

Gambar 3. Korona Fasa S Area Endwinding

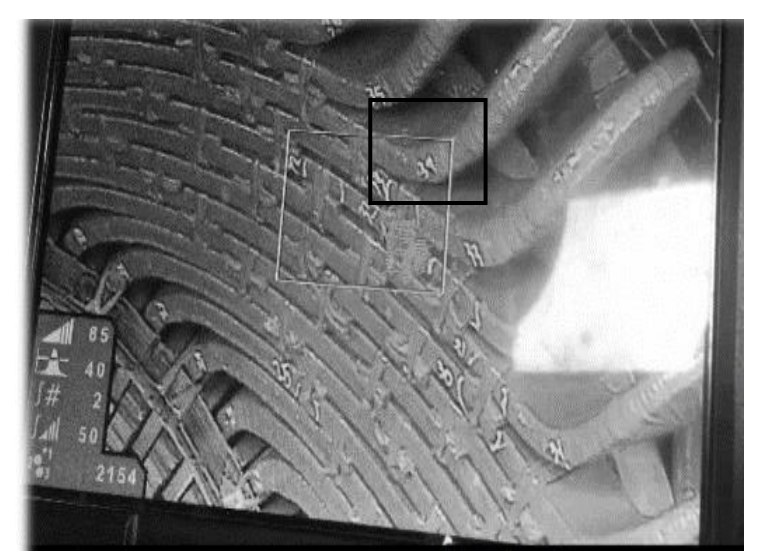

Gambar 4. Korona Fasa T Area Endwinding

\subsection{Analisa Partial Discharge Setelah Overhaul}

Data pengukuran setelah overhaul yang digunakan dalam penelitian ditunjukkan pada Tabel 8.

Tabel 8. Data Pengukuran Partial Discharge Setelah Overhaul

\begin{tabular}{|c|c|c|c|c|c|c|c|c|c|}
\hline \multirow{2}{*}{$\begin{array}{c}\text { Fas } \\
\mathbf{a}\end{array}$} & \multirow[b]{2}{*}{ Tanggal } & \multicolumn{2}{|c|}{ Daya } & \multirow{2}{*}{$\begin{array}{c}\text { Temp } \\
\text { Belitan } \\
\left({ }^{0} \mathrm{C}\right)\end{array}$} & \multirow{2}{*}{$\begin{array}{c}\mathbf{H}_{2} \\
(\text { Psig } \\
\text { ) }\end{array}$} & \multirow[b]{2}{*}{ NQN+ } & \multirow[b]{2}{*}{ NQN- } & \multirow[b]{2}{*}{ Qm+ } & \multirow[b]{2}{*}{ Qm- } \\
\hline & & MW & $\begin{array}{c}\text { MVA } \\
\text { R }\end{array}$ & & & & & & \\
\hline \multirow{3}{*}{$\mathbf{R}$} & 9/4/2019 & 95.3 & 0.2 & 84 & 25 & 188 & - & 52 & 59 \\
\hline & $16 / 7 / 2019$ & 49.2 & 9.8 & 52 & 28 & 69 & 67 & 37 & 33 \\
\hline & $30 / 8 / 2019$ & 80 & 1.1 & 63 & 26.4 & - & 142 & 52 & 60 \\
\hline \multirow{3}{*}{$\mathbf{S}$} & 9/4/2019 & 95.3 & 0.2 & 84 & 25 & 82 & 112 & 38 & 54 \\
\hline & $16 / 7 / 2019$ & 49.2 & 9.8 & 52 & 28 & 99 & 100 & 50 & 54 \\
\hline & $30 / 8 / 2019$ & 80 & 1.1 & 63 & 26.4 & 354 & 289 & 191 & 170 \\
\hline \multirow{3}{*}{$\mathbf{T}$} & $9 / 4 / 2019$ & 95.3 & 0.2 & 84 & 25 & 297 & 265 & 141 & 115 \\
\hline & $16 / 7 / 2019$ & 49.2 & 9.8 & 52 & 28 & 97 & 83 & 84 & 45 \\
\hline & $30 / 8 / 2019$ & 80 & 1.1 & 63 & 26.4 & - & 152 & 47 & 72 \\
\hline
\end{tabular}




\section{Energi dan Kelistrikan: Jurnal Ilmiah}

Vol. 12, No. 1, Januari - Juni 2020, P-ISSN 1979-0783, E-ISSN 2655-5042

https://doi.org/10.33322/energi.v12i1.927

\section{A. Komparasi}

Data pengukuran pada Tabel 9 dikomparasi dengan data pengukuran pada Tabel 3 dan data relative severity yang menunjukkan bahwa, telah terjadi penurunan PD sebesar $228 \mathrm{mV}$ dengan kategori $>90 \%$ (PD high) menjadi PD sebesar $51 \mathrm{mV}$ dengan kategori < 75\% (PD typical). Namun, kondisi tersebut hanya mampu bertahan selama \pm 5 bulan karena PD mengalami kenaikan kembali hingga mencapai $220 \mathrm{mV}$ dengan kategori > 90\% (PD high).

Tabel 9. Analisa Komparasi Sebelum dan Setelah Overhaul

\begin{tabular}{|c|c|c|c|c|c|c|}
\hline Tanggal & Generator & Fasa & Qm+ & Qm- & \multicolumn{2}{|c|}{ Level Partial Discharge } \\
\hline 16 & Pre & $\mathrm{R}$ & 51 & 122 & $<90 \%$ & Moderate \\
\cline { 3 - 7 } Oktober & Overhaul & $\mathrm{S}$ & 228 & 115 & $>90 \%$ & High \\
\cline { 3 - 7 } 2018 & Unit 1 & $\mathrm{T}$ & 35 & 85 & $<75 \%$ & Typical \\
\hline \multirow{3}{*}{$\begin{array}{c}\text { April } \\
2019\end{array}$} & \multirow{3}{*}{$\begin{array}{c}\text { Post } \\
\text { Overhaul }\end{array}$} & $\mathrm{R}$ & 18 & 28 & $<50 \%$ & Low \\
\cline { 3 - 7 } & $\mathrm{S}$ & 51 & 43 & $<75 \%$ & Typical \\
\cline { 3 - 7 } & $\mathrm{T}$ & 25 & 29 & $<50 \%$ & Low \\
\hline \multirow{2}{*}{$\begin{array}{c}\text { Unit 1 } \\
\text { Agustus }\end{array}$} & $\mathrm{R}$ & 57 & 53 & $<75 \%$ & Typical \\
\cline { 3 - 7 } 2019 & & $\mathrm{~S}$ & 176 & 220 & $>90 \%$ & High \\
\cline { 3 - 7 } & & $\mathrm{T}$ & 36 & 44 & $<50 \%$ & Low \\
\hline
\end{tabular}

\section{B. Karateristik}

Berdasarkan analisa data pengukuran dengan menggunakan grafik PRPD pada Tabel 10 menunjukkan bahwa, ketiga fasa masih memiliki pola pulsa yang sama seperti sebelum dilakukan perbaikan pada isolasi saat overhaul. Fasa $\mathrm{R}$ mengalami mechanical dependent $\left(0^{0}\right.$ dan $\left.180^{\circ}\right)$, fasa $\mathrm{S}$ mengalami partial discharge classic negative predominance $\left(45^{\circ} \mathrm{dan} 225^{\circ}\right)$ dan fasa T mengalami open air arc/korona $\left(90^{\circ}\right.$ dan $\left.270^{\circ}\right)$.

Tabel 10. Analisa Karateristik Setelah Overhaul

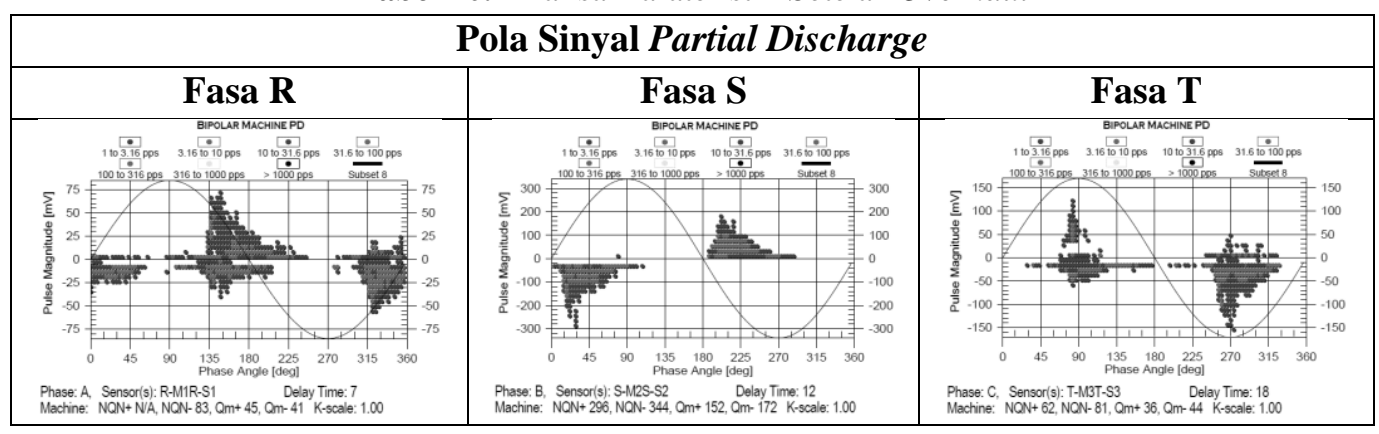

\section{Trending}

Berdasarkan analisa trending data pengukuran pada Tabel 11 menunjukkan bahwa, PD mengalami kenaikan secara gradual (upward trend). Pada fasa $\mathrm{R}$ dan fasa T PD dipengaruhi oleh daya aktif generator (MW) dan temperatur belitan $\left({ }^{0} \mathrm{C}\right)$, sedangkan fasa S PD dipengaruhi oleh daya reaktif (MVAR) yang merujuk pada Tabel 3. Sehingga, perlu menjaga menjaga kestabilan beban generator, menjaga tekanan gas hidrogen sebesar 30 psig sesuai dengan nameplate dan mengurangi daya reaktif yang dibangkitkan $<15$ MVAR. Hal ini menunjukkan bahwa, perbaikan yang dilakukan hanya mampu mengurangi PD selama \pm 5 bulan. 
Tabel 11. Analisa Trending Setelah Overhaul

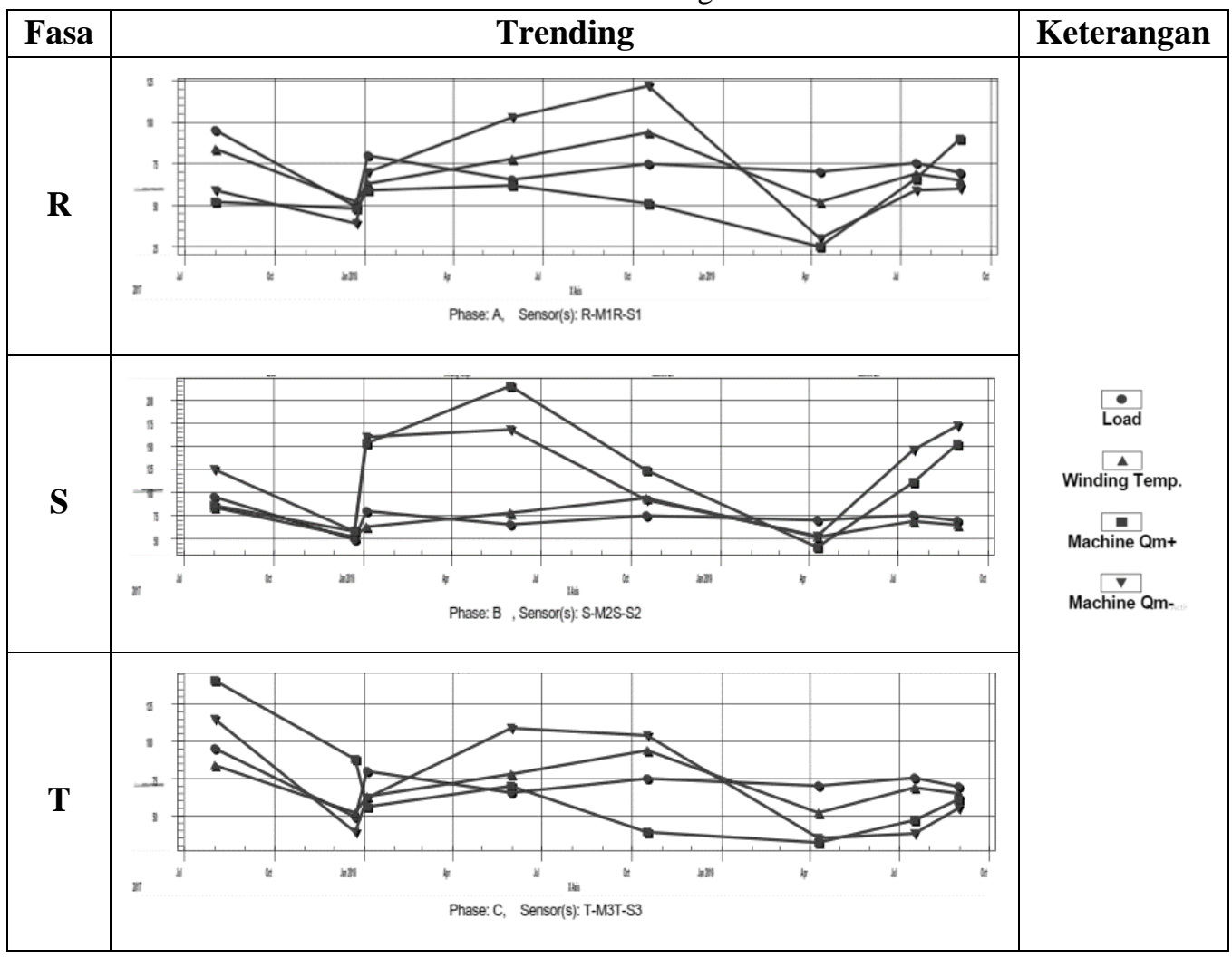

\section{Regresi Linear}

Nilai acuan tetap menggunakan data pengukuran PD generator Unit 6 dengan nilai sebesar $439 \mathrm{mV}$, dengan perhitungan usia layak isolasi setelah overhaul ditunjukkan pada Tabel 12 .

Tabel 12. Perhitungan Usia Isolasi Fasa R Setelah Overhaul

\begin{tabular}{|c|c|c|c|c|c|c|c|c|}
\hline Fasa & Tanggal & Sensitivitas & $X$ & $\mathrm{Y}$ & $X^{2}$ & $\mathrm{Y}^{2}$ & $\mathrm{XY}$ & Fungsi $Y$ \\
\hline \multirow{4}{*}{$\mathrm{R}$} & $9 / 4 / 2019$ & \multirow{3}{*}{$20-340$} & 1 & 28 & 1 & 784 & 28 & \multirow{4}{*}{$\begin{array}{l}\text { Fungsi } a: 11,385 \\
\text { Fungsi } b: 14,385 \\
\text { Usia : } 29,727 \text { bulan } \\
(0,083 \text { tahun })\end{array}$} \\
\hline & $16 / 7 / 2019$ & & 4 & 60 & 16 & 3600 & 240 & \\
\hline & $30 / 8 / 2019$ & & 5 & 90 & 25 & 8100 & 450 & \\
\hline & \multicolumn{2}{|c|}{ Total $\left(\sum\right)$} & 10 & 178 & 42 & 12484 & 718 & \\
\hline \multirow{4}{*}{ S } & $9 / 4 / 2019$ & \multirow{3}{*}{$20-340$} & 1 & 51 & 1 & 2601 & 51 & \multirow{4}{*}{$\begin{array}{l}\text { Fungsi } a: 21,077 \\
\text { Fungsi } b: 30,577 \\
\text { Usia : } 13,668 \text { bulan } \\
\quad(0,038 \text { tahun })\end{array}$} \\
\hline & $16 / 7 / 2019$ & & 4 & 146 & 16 & 21316 & 584 & \\
\hline & $30 / 8 / 2019$ & & 5 & 172 & 25 & 29584 & 860 & \\
\hline & \multicolumn{2}{|c|}{ Total $\left(\sum\right)$} & 10 & 369 & 42 & 53501 & 1495 & \\
\hline \multirow{4}{*}{ T } & $9 / 4 / 2019$ & \multirow{3}{*}{$20-340$} & 1 & 29 & 1 & 841 & 29 & \multirow{4}{*}{$\begin{array}{l}\text { Fungsi } a: 20,154 \\
\text { Fungsi } b: 7,154 \\
\text { Usia }: 58,548 \text { bulan } \\
\text { (0,163 tahun) }\end{array}$} \\
\hline & $16 / 7 / 2019$ & & 4 & 42 & 16 & 1764 & 168 & \\
\hline & $30 / 8 / 2019$ & & 5 & 61 & 25 & 3721 & 305 & \\
\hline & \multicolumn{2}{|c|}{ Total $\left(\sum\right)$} & 10 & 132 & 42 & 6326 & 502 & \\
\hline
\end{tabular}

Hasil perhitungan pada Tabel 12 menunjukkan bahwa, fasa $\mathrm{R}$ mengalami kenaikan 1 bulan (0,083 tahun) menjadi 6 tahun 6 bulan 22 hari atau diprediksi sampai dengan \pm 24 Februari 2025, fasa $\mathrm{S}$ mengalami kenaikan 14 hari $(0,038$ tahun) menjadi 2 tahun 1 bulan 21 hari atau diprediksi sampai dengan \pm 22 September 2021, dan fasa T mengalami kenaikan 1 bulan 29 hari (0,163 tahun) menjadi 6 tahun 10 bulan 5 hari atau diprediksi sampai dengan \pm 4 Juni 2025 . 


\section{Energi dan Kelistrikan: Jurnal Ilmiah}

Vol. 12, No. 1, Januari - Juni 2020, P-ISSN 1979-0783, E-ISSN 2655-5042

https://doi.org/10.33322/energi.v12i1.927

\section{KESIMPULAN DAN SARAN}

Korona dan PD disebabkan oleh permukaan isolasi yang rusak akibat kontaminasi minyak seal oil bearing nomor 5 dan load \& thermal cycling generator, dengan usia tersingkat isolasi belitan stator sebelum overhaul selama 2 tahun 1 bulan 7 hari dan setelah overhaul selama 2 tahun 1 bulan 21 hari. Hal ini menunjukkan bahwa, perbaikan yang dilakukan dengan metode re-varnish tidak mampu mengurangi PD high pada fasa $\mathrm{S}$ dan tidak mampu menghilangkan korona pada fasa $\mathrm{T}$, dengan kenaikan usia isolasi belitan stator generator Unit 1 tidak terlalu besar. Sehingga, diperlukan menjaga kestabilan beban generator untuk mencegah kenaikan korona dan PD, memperpendek monitoring PD dari 6 bulan menjadi 3 bulan dengan parameter generator yang tidak jauh berbeda dan dilakukan perbaikan yang tepat pada isolasi yang telah terindikasi korona dan PD.

\section{UCAPAN TERIMAKASIH}

Penulis mengucapkan terima kasih kepada Universitas Islam Sultan Agung dan PLTG Jawa Tengah yang telah memberi dukungan yang membantu pelaksanaan penelitian dengan memberikan ijin untuk pengamatan dan pengambilan data untuk penulisan artikel ini.

\section{DAFTAR PUSTAKA}

[1] Iris Power LP., 2006., PD Seminar - Module 1: Basic PD Theory., Detection and Charateristics., Iris Power Engineering. Inc., Canada.

[2] Pasaribu, Better., 2013., On-line Partial Discharge Testing for Motors \& Generators., PT. Dielektrika Persada Teknik., Banten.

[3] Paoletti G.J., A. Golubev., 1999., Partial Discharge Theory and Application to Electrical Systems., IEEE Paper., Amerika.

[4] Stone G.C., C. Chan., H.G. Sedding, 2016, Online Partial Discharge Measurement in Hydrogen Cooled Generators, Electrical Insulation Conference 19-22 June, Canada.

[5] Setyoadi., 2012., Analisis Permasalahan Partial Discharge pada Isolasi Belitan Stator Generator 11,8 kV., FTUI., Jakarta.

[6] Husnul, Muhammad., 2008., Deteksi dan Analisis Peluahan Parsial pada Belitan Stator Generator., FTUI., Jakarta.

[7] Iris Power LP., 2019., Appendix - Data Analysis of Results THRU 2017., Iris Power Engineering. Inc., Canada.

[8] Iris Power LP., 2013., Intepretation of Partial Discharge Version 4., Iris Power Engineering. Inc., Canada.

[9] Yuliara, I Made., 2016., Modul Regresi Linear Sederhana., FMIPA Udayana., Bali.

[10] General Electric., 1993., GE Generator-GD 98812., General Electric Company., Amerika. 